\title{
Diatoms as Indicators of Anthropogenic Changes in Water Quality in Mucheke and Shagashe Rivers, Masvingo, Zimbabwe
}

\author{
Bere, T. ${ }^{1, *}$; Chakandina kira, A.T. ${ }^{1}$
}

${ }^{1}$ Department of Freshwater and Fishery Science, Chinhoyi University of Technology, Off Ha ra re-Chirundu Rd, P. Bag 7724, Chinhoyi, Zmbabwe

*Corresponding a uthor: taubere@yahoo.com/tbere@cut.ac.zw

\section{Abstract}

The most widely used method of water quality assessment, physic al and chemic al variables a ssessment is less reliable compared to the use of biologic al methods such as diatom assemblages. The objec tive of this study was to (1) assess response of diatom assemblages to anthropogenic changes in water qua lity in two rivers that $\mathrm{dra}$ in a $\mathrm{n}$ urban area in Masvingo, Zmbabwe, (2) test the applic ability of the Trophic diatom index (TDI) and Pampean diatom index (PDI) in assessing water quality in the study area. Water quality sampling and benthic diatom community data were collected in May to J uly 2012 from nine sampling stations in the Mucheke and Shaga she Rivers, Zmbabwe.The data were subjected to canonic al correspondence a nalysis (CCA) to determine environmental gradients a long which the diatom species were distributed. Diatom-based biotic indicesi.e. the TDI and PDI were used to determine the ecological sta tus of study streams in relation to human-induced stressors. Pearson's correlation was used to determine the relationship between the calculated index scores and measured physic al and chemic al water quality data. Two-way ANOVA was used to compare these correlation values among sampling stations. The PDI and TDI scores on all the sampling sites showed signific ant correlations with physic al and chemic al 
variables. Thus, the indic es proved useful in providing an indic ation of the qua lity of the investigated waters. No signific ant differences in physic al and chemic al va ria bles were recorded between the three sampling periods. Diatom community structure closely reflected this gradient, with communities from polluted sampling stations (U1, U2, U3, U4 and U5) being different from other communities. Polluted sampling stations were associated with pollution tolerant species such as Diatoma vulgaris, Nitzsc hia palea, Fragilaria biceps, Achnanthes exigua and Cymatopleura solea. Dia toms communities demonstrated potential for acting as indic ators of changes in water quality due to organic and industrial pollution and are therefore recommended for use in research and monitoring of water bodies by relevant governmental and non-governmental organizations in Zmbabwe.

Keywords: dia toms, biological monitoring, pollution, water quality, dia tom indices.

\section{Introduction}

The success of huma n civilization is la rgely due to our skills as ecosystem eng ineers (KIM; WEA VER, 1994). Although these engineering a ctivities a re prima rily directed towardsachieving some specific purposes (e.g. industrial production), most have major indirect and unintended effects on ecosystems (TANNER, 2001). Freshwater ecosystems a re among the most endangered ecosystems in the world and the decline in freshwater biodiversity is far greater than in most affected te rrestrial ec osystems (DUDGEON et al., 2006). Disposal of huma $n$ waste has now become one of the greatest challenges of urbanization in both developed and developing countries (BERE, 2007; BEYENE et al., 2010). This problem is more severe in developing countries like Zmbabwe where rapid urbanization, coupled with rapid population growth, is not matched by associa ted technic al standards for systems such as sewage treatment, collection of garbage and urban drainage due to economic problems and socio-political bewild erments (DUBE; SWATUK, 2002; BERE; MANGAD正, 2014; MANG AD正 et al., 2016; MWEDZ et al., 2016). In such instances, waterways are used for disposal of sewage and industrial effluent leading to problems such as the eutrophication and organic pollution (HARPER, 1992; BERE, 2007).

Two threads of basic approaches to the assessment of water quality deterio ration in streams run through the literature; physic al and chemical methods and biological methods (BERE; TUNDISI, 2010). Physic al and chemical methods provide, at best, a fragmented overview of the state of aquatic systems, as sporadic or periodic sampling cannot reflect fluxes of efflue nt disc ha rge (TAYLOR et al., 2007b). The chemistry at any given time is a snapshot of the water quality at the time of sampling ignoring temporal variation of wa ter quality va riables that is usua lly high in streams (TAYLOR et al., 2007b). In 
contrast, biological monitoring (the theory behind which decoding environmental change information enshrined in biota) gives a time-integrated indic ation of the water qua lity components because of the capa city of reflecting cond itions that a re not present at the time of sample collection and a na lysis (KARR, 1981; TAYLOR et al., 2007b). Biological monitoring is a fast and cost effective approach for assessing the effects of environmental stressors, making it a particularly essentia I tool for the management of rivers in developing countries (ROUND, 1991).

Benthic diatoms are amongst the commonly used biological indic ators because they offer several advantages compared to other potential biological indic a tors like fish, macro invertebrates and plants (HARDING et al., 2005; BERE, TUNDISI, 2010; SMOL; STOERMER, 2010). Dia toms, a type of uni-c ellular algae, have a short developmental cycle (a few hours to several days), depending on species and environmental conditions, a rich species composition and wide distribution thus making them ideal for bio-monitoring (RIMET, BOUC HEZ, 2011). Changes in water chemistry will inhib it the multip lic a tion of some species, while supporting that of others (tolerant species), thus the percentage composition of certa in species within a community will be changed (WERNER, 1977). Dia to ms a re sensitive to changes in nutrient concentrations i.e. growth response is directly affected by changes in prevailing nutrient concentrations and light a va ila bility (ROUND, 1991; SMO L, STO ERMER, 2010; WOOD et al., 2016).
Each taxon has a specific optimum and tolerance for nutrients such as phosphate and nitrogen, and this is usua lly qua ntifia ble. While diatoms collectively show a broad range of tolerance along a gradient of changes in water quality, ind ividual species have specific water chemistry requirements (SMOL, STO ERMER, 2010; HARDING, TAYLOR, 2011). Up to $70 \%$ of what happens to water quality can be reflected in diatom assemblages (TAYLOR et al., 2007a). Although over the last few decadesa number of biological monitoring methods have been developed for the a ssessment of water quality in streams, these have ra rely been applied in Africa, especially in Zmbab we (PHIRI et a I., 2007; BERE; MANGAD正, 2014; MANG AD正 et al., 2015, 2016). For instance, dia tom-based water qua lity a ssessment protocols have been developed and used extensively elsewhere but with little use in Zmbabwe.

Isolated cases where attempts have been made to assess water quality using dia to ms rely hea vily on information from other countries. However, there is evidence that this information is less suc cessful when a pplied in other a reas (PIPP, 2002). This is due not only to the floristic differences and occurrence of endemics a mong regions, but also to the environmental differences that modify species responses to wa ter-qua lity c ha rac teristic S (POTAPOVA, CHARLES, 2002; TAYLO R et al., 2007b). The first objective of the present study was to a ssess response of diatom a ssemblages to anthropogenic changes in water quality in two rivers that dra in a $\mathrm{n}$ urban a rea in south-eastem Zmbabwe. The second 
objective was to test the applicability of PDI and TDI in assessing water quality in the study area. In particular, we asked: (1) to what extent observed changes in water quality reflect themselves in diatom communities in the study streams and (2) to what extend PDI and TDI metrics detect changes in water quality in the study streams. We hypothesised that diatom communities are capable of reflecting changes in water quality, with PDI and TDI metric s being sensitive to water quality changes in the study region because of occurrence of ubiquitous taxa that probably have similar environmental tolerances to those recorded for these two indices.

\section{Materials and Methods}

\section{Study area}

The area under study is loc ated in the so uthern parts of Zmbabwe (Figure 1 ) in the Runde catc hment a rea. The two study rivers, Mucheke and Shagashe, fall in a subtropical steppe/low-latitude semi-arid climatic region were the average temperature and ra infall pattems a re $19.4^{\circ} \mathrm{C}$ and $623 \mathrm{~mm}$ per annum. Headwaters of the study rivers fall ma inly within a $n$ agricultural a rea where crop production and a nimal husbandry is practiced. From the agricultural a rea, the streams pass through urban area of the city of Masvingo, a medium-sized city with a population of 88554 (Zmbabwe National Sta tistic s Agency - ZNSA) loc a ted at the confluence of these rivers. Due to rapid population growth, that is not matched by upgrading of systems such as sewage treatment, collection of garbage and urban drainage due to economic problems and socio-political bewilderments, the capacity of municipal sewage treatment facilities has been exceeded. Poor maintenance and breakdowns of these facilities is a lso very common because of the financial constrains currently facing the munic ipality. Options that a re a vailable for sewage treatment such as biological nutrient removal plants, conventiona I stabilization ponds, septic tanks and blair la trines a re not being exploited to combat eutrophication because of the nation's economic and social problems (MAPIRA, 2011). Therefore, the study strea ms receive untreated or semi-treated effluent from sewage treatment plants and bust sewage pipes as well as other diffuse sources as they pass thorough the city.

Nine sampling sites were established along the two rivers: two sites ( $R 1$ and R2) in the relatively less impacted agric ultural and forested headwaters to act as reference sites; five sites (U1, U2, U3, U4 and U5) in the polluted urban area; and two sites (D1 and D2) in downstream area after the urban area where water quality is expected to improve due to river self-purific a tion c a pa city (BERE, 2007). The rational for choosing the sampling sites was to obta in a pollution gradient of all the stream systems from rela tively unpolluted a gric ultura I head wa ters to highly polluted urban downstream sites. Monthly samplings of diatom and water quality were conducted from may to july 


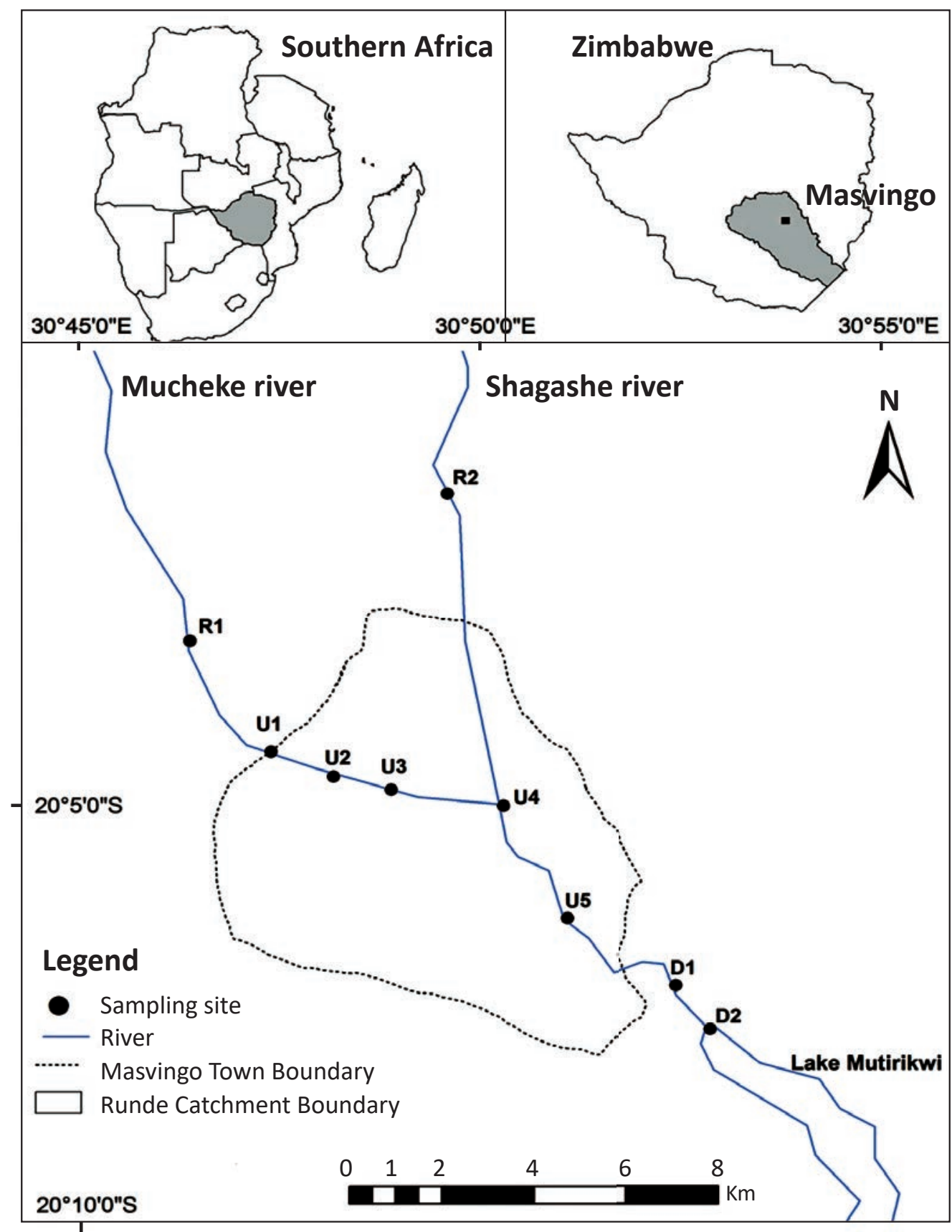

Figure 1 - The location of the Mucheke and Shagashe rivers showing the location of the sampling stations (R1 and R2 = reference sites; U1-U5 = urban sites; D1 and D2 = downstream sites).

2012. The dry season was chosen to avoid variable effects of the rainy season such as great variations in water level and velocity, floods and inundations. These variations affect the growth, development of diatoms and the relative abundance of different species (ROUND, 1991).
Water quality sampling and analys is

At each site, dissolved oxygen (DO), electric al conductivity, specific conductivity, nitrate $\left(\mathrm{NO}_{3}\right)$, a mmonium, 
a mmonia, chloride, total dissolved solids (TDS), salinity and $\mathrm{pH}$ were measured using a portable meter (YSI professional plus, Yellowstone. USA).

\section{Epilithic diatom sampling}

At each site, epilithic diatoms were sampled by brushing stones with a tooth brush following (HARDING et al., 2005). Prior to sampling of epilithic surfaces, all substrata were gently shaken in the stream water to remove any loosely attached sediments and non-epilithic diatoms. At least five pebble-to-cobble $(5-15 \mathrm{~cm})$, sized stones were randomly collected along each sampling stretch, brushed and the resulting diatom suspensions were pooled to form a single sample which was then put in a labeled plastic container. The dislodged material was decanted into a sample bottle and preserved using formalin to be identified in the laboratory.

In the laboratory, sub-samples of the diatom suspensions were cleaned of organic material using wet combustion with concentrated sulphuric acid and hydrogen peroxide and mounted in Naphrax (Northem Biological supplies Ltd., UK, R1 $=1.74$ ) following Biggs and Kilroy (2000). Three replic ate slides were prepared for each sample. A total of 300-650 valves persample (based on counting efficiency determination method by Pappas and Stoermer (1996) were identified and counted using a compound mic roscope (× 1000; Nilc on, Alpha phot 2, Type YS2-H,
China). The diatoms were identified to species level based mainly on studies from South Africa (TAYLOR et al., 2007a); stud ies from other tropic al regions were consulted when necessary e.g. (MET\&LTIN, LANG E-BERTALOT, 1998).

\section{Indices calculation}

The PDI and TDI were calculated following Gómez and Lic ursi (2001) and Kelly et al. (2001) respectively. The PDI values range from 0 to 4 as follows: 0-0.5 (very good), > 0.5-1.5 (good), > 1.5-2 (acceptable); $>2-3=$ bad and $>$ 3-4 (very bad) water quality.Values for the TDI range from 1 (very low nutrient concentrations) to 5 (very high nutrient concentrations). The percentage pollution tolerance taxa is then calculated as a measure of the reliability of the trophic dia tom index. Different categories a re drawn out from the percentage values to come up with an interpretation of the proportion of count composed of taxa tolerant to organic pollution.

\section{Statistical analysis}

A two-way a nalysis of va ria nce (Two-Way ANOVA) with Tukey's post hoc HSD tests was used to compare means of physical and chemic al va riables a mong the three sampling station categories and between the three sampling periods. Pearson's correlation was used to determine the relationship between the calculated 
index scores (TDI and PDI) and measured physical and chemical water qua lity data. One-way ANOVA was used to compare the PDI and TDI scores among sampling sta tions.

Multivariate data a nalyses were performed on the diatom community data to explore the main gradients of floristic va riation and to detect and visualize simila rities in dia to $m$ sa mples. Prelimina ry detrended correspondence a nalysis (DCA) was applied on diatom data set to determine the length of the gradient. The DCA revealed that the gradient was greater than three standard deviation units, justifying the use of unimodial ordination tec hniques (ter Bra ak and Verdonschot, 1995). Thus, canonical correspondence analysis (CCA) was performed to relate dia tom community structure to simulta neous effects of pred ic tor environmental va ria bles, and to explore the relationship amongst and between species and predictor variables. Preliminary C CA identified collinearvariables and selected a subset on inspection of variance inflation factors (VIF $<20$ ); (Ter Bra ak and Smila uer, 2002). Monte Carlo permutation tests (999 unrestric ted permutations, $p \leq 0.05$ ) were used to test the significance of the axis and determine if the selected environmental variables could expla in nearly a s much variation in the diatom community structure as all the environmental va ria bles combined. DCA and CCAs were performed using CANOCO version 4.5 (TER BRAAK; SMILAUER, 2002). All other statistic al tests were performed with Pala eontological Sta tistics So ftwa re (PAST) Version 2.16 (Ha mmer et al., 2001).

\section{Physical and chemical variables}

The values of the physioc hemical variables recorded in the Mucheke and Shagashe River during this study a re summarized in Table 1 . A tota I of 10 environmental va ria bles were a na lyzed. Generally, water quality deteriorated at sites that were at or near disc harge points a long the two rivers (Table 1 ). Conductivity and TDS were signific a ntly high in U2, U5 and D1 compared to.R1, R2 and D2 (ANOVA, $P<0.05$ ). There were no signific ant differences in $\mathrm{pH}$ and salinity among sampling stations (ANOVA, P > 0.05). Ammonia, ammonium, $\mathrm{NO}_{3}$ specific conductance and $\mathrm{Cl}$ were signific antly high in urba $n$ sampling stations (U1-U5) (ANOVA, $\mathrm{P}<0.05)$, while DO was signific antly low in the same (ANOVA, $P>0.05$ ) compared to the reference and downstream sites.

\section{Diatom indices}

The PDI and TDI scores based on all the site categories showed signific ant correlations $(P<0.05)$ with physical and chemica I variables (Table 2). Significant differences (ANOVA, $P<0.05$ ) in the PDI sc ores based on different site categories were recorded, with reference sites R1 and R2 classified as good. Downstream sites D1 and D2 were generally classified as acceptable and good respectively, while urban sites U1, U2, U3, U4 and U5 were classified as bad.

Simila rly, signific a nt differences (ANOVA, P < 0.05) in the TDI scores 


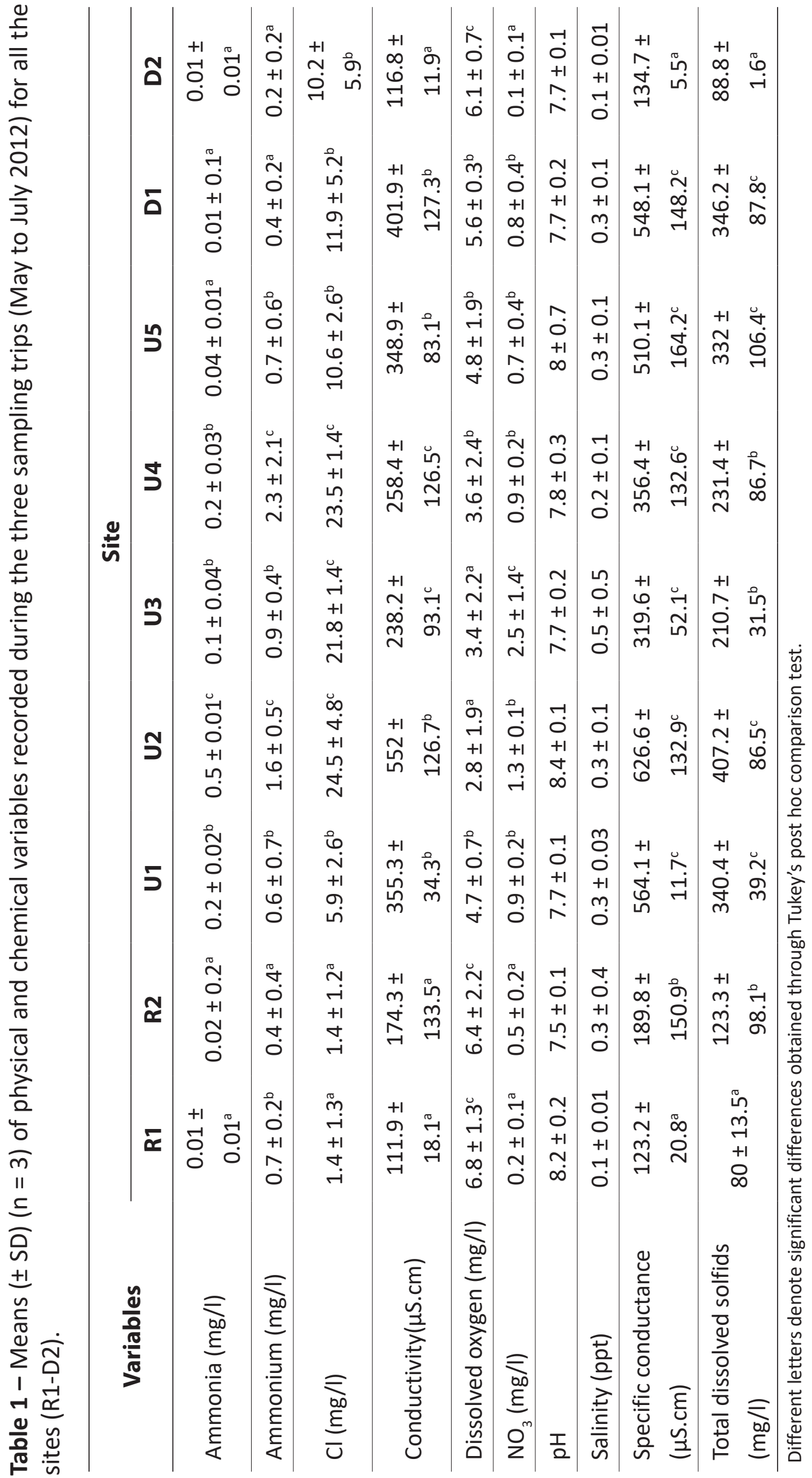


based on different site categories were recorded (Figure 3). Reference sites (R1 and R2) as well as downstream sites (D1 and D2) had low percentage pollution tolerant taxa (below $20 \%$ ), which means they were free from significant organic pollution (Figure 3). Urban sites generally had high percentage pollution tolerant taxa (a bove $20 \%$; Figure 3) ind ic a ting some evidence of organic pollution and in some cases (sites U3, U4 and U5) organic pollution was likely to be contributing signific a ntly to eutro phic ation. Correlations between the PDI scores and physic al and chemic al variables were a lso generally lower compared to those between the TDI scores and physical and chemical variables.

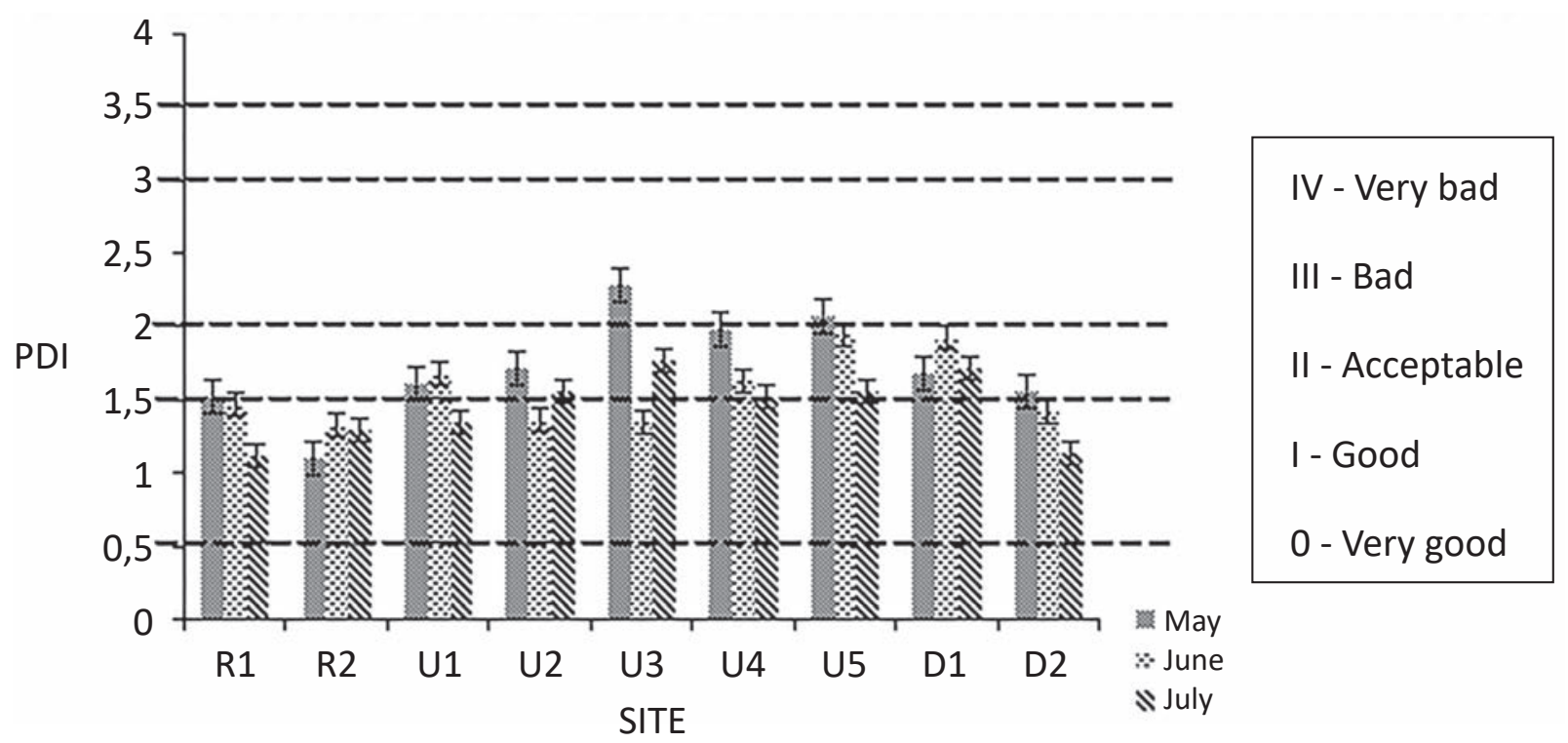

Figure 2 - The Pampean diatom index (PDI) scores recorded at sites along the Mucheke and Shagashe rivers for the study period (may to june).

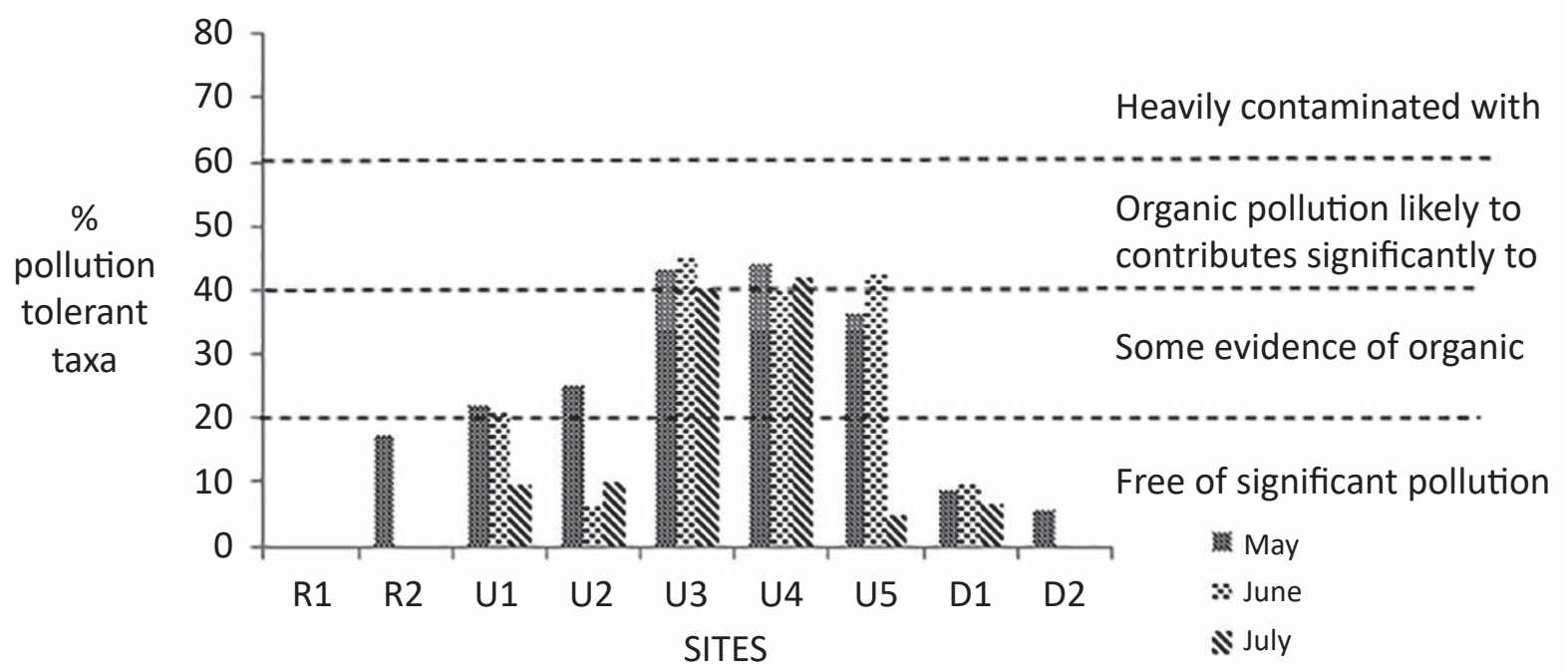

Figure 3 - Percentage pollution tolerant taxa from the nine sampling sites. 
Table 2 - Pearson's correlation between diatom indices and environmental variables.

\begin{tabular}{lcc}
\hline \multirow{2}{*}{ Parameter } & \multicolumn{2}{c}{ Metric } \\
\cline { 2 - 3 } & TDI & PDI \\
\hline Ammonia $(\mathrm{mg} / \mathrm{l})$ & 0.34 & -0.16 \\
\hline Ammonium $(\mathrm{mg} / \mathrm{I})$ & 0.48 & 0.2 \\
\hline $\mathrm{Cl}(\mathrm{mg} / \mathrm{l})$ & 0.16 & 0.07 \\
\hline Conductivity $(\mu \mathrm{S} . \mathrm{cm})$ & 0.31 & 0.29 \\
\hline Dissolved oxygen $(\mathrm{mg} / \mathrm{l})$ & -0.18 & -0.03 \\
\hline NO3 (mg/l) & -0.09 & -0.2 \\
\hline pH & -0.2 & 0.07 \\
\hline Salinity (ppt) & 0.48 & -0.1 \\
\hline Total dissolved solids $(\mathrm{mg} / \mathrm{l})$ & 0.41 & 0.38 \\
\hline
\end{tabular}

\section{Community composition}

A total of 39 diatom species belonging to 25 genera were identified in all nine sampling sites (Table 3). Species composition in terms of species ric hness, species diversity, dominance and evenness is in the same range for reference and downstream sites compared to urban sites.

The results of CCA are presented in Figure 4. The first fouraxes of the selected explora tory variables a c counted for $79.9 \%$ of the total variance in the community data (Table 2). Axis 1 and 2 signific antly expla ined $26.4 \%$ and $16.3 \%$, respectively, of the diatom species va ria nce (Table 2; Monte $\mathrm{C}$ arlo unrestricted permutation, $\mathrm{P}$ $<0.05)$. CCA Axes 1 and 2 separated the sites into 3 groups. The first group consisted of less polluted sites R1 and R2 that were positively a ssociated with the first axis. Dia to $m$ species characterising these sites include species such as Achnanthidium minutissimum, Aulacoseira distans, Enc yonema silesiacum, Enc yonopsis minuta, Cymatopleura solea, Eunotia flexuosa Diploneis subovalis, Cymbella kappii, Eunotia flexuosa, Fragilaria nanana, Rhopa lodia gibba, Dia desmis confervacea, Bra chysira neoexilis, Gomphonema la tic ollum,C yma to pleura solea, Pinnula ria acrosphaeria, Gomphonema minitum, Pinnularia subcapita ta and Sta urosirella pinnata. The second group consisted of highly polluted sites (U1-U5) that were negatively associated with the first and positively associated with the second axis, respectively (Figure 4). These sites were associated with high ammonium, ammonia and nitrate levels. Diatom species characterising these sites include species such as Frag ila ria bic eps, Fragila ria ulna, Rhoicosphenia abbreviate, Cyclotella meneghiniana, Nitzsc hia palea, Gomphonema parvulum, Cyclotella sp $p$, Pinnularia confirma, Pinnula ria virid iformis. This group of species was associated with high levels of a mmonia, a mmonium and nitra te as compared to the rest of the species. The third group consisted of medium polluted sites D1 and D2 that were negatively associated with the first and second axis. These sites were associated with high salinity and $\mathrm{pH}$ levels. Nutrient levels were generally low compared to those of sites U1-U5. Sites D1and D2 wereassociated Pleurosigma 
elongatum, Ta bellaria flocculosa, frustulum, Gomphonema insigne, Fallacia Sellaphora stroemii, Sellaphora seminulum, monoculata, Achna nthes exigua and Pla nothidium frequentissimum, Nitzschia Diatoma vulgaris.

Table 3 - Mean values of species richness, diversity, dominance and evenness.

\begin{tabular}{lccccccccc}
\hline & S1 & R2 & U1 & U2 & U3 & U4 & U5 & D1 & D2 \\
\hline Speciesrichness & $8 \pm 1$ & $10 \pm 2$ & $8 \pm 1$ & $10 \pm 0$ & $7 \pm 1$ & $5 \pm 1$ & $6 \pm 2$ & $10 \pm 2$ & $9 \pm 2$ \\
\hline \multirow{2}{*}{ Shannondiversity } & $1.6 \pm$ & $2.1 \pm$ & $1.9 \pm$ & $2.1 \pm$ & $1.8 \pm$ & $1.5 \pm$ & $1.5 \pm$ & $1.8 \pm$ & $1.8 \pm$ \\
& 1.8 & 0.1 & 0.3 & 0.04 & 0.2 & 0.1 & 0.4 & 0.3 & 0.2 \\
\hline \multirow{2}{*}{ Dominance } & $0.3 \pm$ & $0.1 \pm$ & $0.2 \pm$ & $0.1 \pm$ & $0.2 \pm$ & $0.2 \pm$ & $0.3 \pm$ & $0.3 \pm$ & $0.2 \pm$ \\
& 0.1 & 0.02 & 0.1 & 0.01 & 0.03 & 0.03 & 0.1 & 0.1 & 0.04 \\
\hline \multirow{2}{*}{ Evenness } & $0.6 \pm$ & $0.8 \pm$ & $0.8 \pm$ & $0.8 \pm$ & $0.9 \pm$ & $0.8 \pm$ & $0.7 \pm$ & $0.6 \pm$ & $0.7 \pm$ \\
& 0.1 & 0.05 & 0.1 & 0.03 & 0.05 & 0.05 & 0.1 & 0.2 & 0.02 \\
\hline
\end{tabular}



Figure 7-Ordination diagram based on canonical correspondence analysis (CCA) of diatom species composition in nine sampling sites in respect with six environmental variables. 
Table 4 - Diatom species codes used in the canonical correspondence analysis.

\begin{tabular}{lc}
\hline \multicolumn{1}{c}{ Species } & Code \\
\hline Achnanthes exigua & Aexi \\
\hline Achnanthidium minutissimum & Amin \\
\hline Aulacoseira distans & Adis \\
\hline Brachysira neoexilis & Bneo \\
\hline Cyclotella meneghiniana & Cmen \\
\hline Cyclotella species & Cspp \\
\hline Cymatopleura solea & Csol \\
\hline Cymbella kappii & Ckap \\
\hline Diadesmis confervacea & Dcon \\
\hline Diatoma vulgaris & Dvul \\
\hline Diploneis subovalis & Dsub \\
\hline Encyonopsis minuta & Emin \\
\hline Encyonema silesiacum & Esil \\
\hline Encyonema sitesiam & Esit \\
\hline Eunotia flexuosa & Efle \\
\hline Fallacia monoculata & Fmon \\
\hline Fragilaria biceps & Fbic \\
\hline Fragilaria nanana & Fnan \\
\hline Fragilaria ulna & Fuln \\
\hline Gomphonema affine & Gaff \\
\hline
\end{tabular}

\begin{tabular}{lc}
\hline \multicolumn{1}{c}{ Species } & Code \\
\hline Gomphonema insigne & Gins \\
\hline Gomphonema laticollum & Glat \\
\hline Gomphonema minutum & Gmin \\
\hline Gomphonema parvulum & Gpar \\
\hline Nitzschia frustulum & Nfru \\
\hline Nitzschia palea & Npal \\
\hline Nitzschia reversa & Nrev \\
\hline Pinnularia acrosphaeria & Pacr \\
\hline Pinnularia confirma & Pcon \\
\hline Pinnularia subcapitata & Psub \\
\hline Pinnularia viridiformis & Pvir \\
\hline Planothidium frequentissimum & Pfre \\
\hline Pleurosigma elongatum & Pelo \\
\hline Rhoicosphenia abbreviata & Rabb \\
\hline Rhopalodia gibba & Rgib \\
\hline Sellaphora seminulum & Ssem \\
\hline Sellaphora stroemii & Sstr \\
\hline Staurosirella pinnata & Spin \\
\hline Tabellaria flocculosa & Tflo \\
\hline
\end{tabular}

\section{Discussion}

\section{Water quality}

The results of the physic al and chemical variables in the study showed that pollution levels, especially orga nic pollution and eutrophic ation, differed among the sites sampled (Table 1). Conductivity, a mmonium, ammonia, chloride and nitrate were signific a ntly higher in sites that were

near or at a pollution point in the urban a reas. Industrial, domestic and sewage effluent disposals a re the ma in causes of decrease in the water quality along the Mucheke and Shaga she River system. These high levels of nutrients a re assoc ia ted with deterioration of water quality and eventually lead to eutrophic ation and changes in diatom species composition (BERE, 2010). 
Diatom community structure in relation

to environmenta 7 variables

Dia to m community struc ture and composition closely followed the observed changes in pollution levels, with less polluted sites R1 and R2 being associated with diatom communities that were different from highly polluted sites U1, U2, U3, U4 and U5. C luster analysis of sampling stations based on epilithic diatom communities in streams of the Mucheke and Shagashe river clearly reflected the effects of pollution (Figure 2). The epilithic algal communities in this study were prima rily affected by organic pollution and nutrient concentrations in the streams resulting from urban runoff as confirmed by the findings of Beyene et al. (2010). Diatoms have an important role in biological monitoring of lotic systems as they have shown capacity to respond to changes in water quality. Ammonia, Ammonium, sa linity, $\mathrm{pH}$ and nitra te were found to be important in structuring benthic diatom communities in the study a rea (Figure 4). Other studies have also shown that nutrients (ammonia, ammonium and nitrate)are the primary drivers of periphyton community struc ture and biomass (BIGGS, THOMSEN, 1995; J OWEIT, BIGGS, 1997). Nonetheless, a review of litera ture ca rried out by (SAROS, FRITZ, 2000) showed that sa linity may influence nutrient availability to primary producers, as well as nutrient requirements and uptake by diatoms. pH exerts a direct physiologic al stress on dia toms (G ENSEMER, 1991), and also strongly influences other water chemistry va riables (SIG G, STUMM, 1981). Based on the CCA (Figure 4), sites that were relatively more polluted had pollution tolerant species such as Nitzsc hia palea, Gomphonema parvulum, Cyclotella spp, Pinnularia confirma and Pinnularia virid iformis. These species are known to be resistant to heavy metal and organic pollution (ROUND, 1991; BERE, TUNDISI, 2010). Whereas, reference sites R1 and $\mathrm{R} 2$ were characterized by low pollution tolerant speciessuch as Fra gila ria nanana, Rhopalodia gibba, Diadesmis confervacea, Bra chysira neoexilis, Gomphonema la tic ollum,Cymatopleura solea,Pinnula ria acrosphaeria, Gomphonema minitum, Pinnularia subcapitata and Sta urosirella pinnata. These species a re mainly found in oligo- to mesotrophic water with moderate cond uc tivity (VAN DAM et al., 1994; BERE, TUNDISI, 2011).

\section{Applicabi7ity of TDI and PDI to the study area}

The signific a nt correlations between TDI and PDI index values and physical and chemical chara c teristic s of streams recorded in this study indic ate that these indices may be used to reflect general changes in water quality of rivers and streams of Zmbabwe (Table 2). Values of the TDI and PDI indices showed signific ant differences between reference sites $R 1$ and R2 and heavily polluted urban sites U1-U5 (Figures 2 and 3). This is supported by (Bate et al., 2004) who found that most dominant dia tom species found in South Afric a n rivers were already recorded in 
intemational studies. Thus, most foreign diatom indices may be used in the study a rea as they are based on the ecology of widely distributed or cosmopolitan taxa. In conclusion, it can be said that the PDI and TDI a re applic able to the study area. Diatoms have a $\mathrm{n}$ important role in biological monitoring of lotic systems as they have shown capacity to respond to changes in water quality.

\section{Conclusion}

In conclusion, orga nic and ind ustria I effluent has a great effect on the water

\section{References}

BATE, G., SMAILES, P. and ADAMS, J., 2004. A water quality index for use with diatoms in the assessment of rivers. Water SA, vol. 30, no. 4, pp. 493-498.

BERE, T., 2007. The assessment of nutrient loading and retention in the upper segment of the Chinyika River, Harare: Implications for eutrophication control. Water SA, vol. 33, no. 2.

BERE, T., 2010. Benthic diatom community structure and habitat preferences along an urban pollution gradient in the Monjolinho River, São Carlos, SP, Brazil. Acta Limnologica Brasiliensia, vol. 22, no. 1, pp. 80-92.

BERE, T. and MANGADZE, T., 2014. Diatom communities in streams draining urban areas: community structure in relation to environmental variables. Tropical Ecology, vol. 55, no. 2, pp. 271-281.

BERE, T. and TUNDISI, J., 2010. Biological monitoring of lotic ecosystems: the role of diatoms. Brazilian Journal of Biology, vol. 70, no. 3, pp. 493-502.

BERE, T. and TUNDISI, J., 2011. Influence of ionic strength and conductivity on benthic diatom communities in a tropical river (Monjolinho), São Carlos-SP, Brazil. Hydrobiologia, vol. 661, no. 1, pp. 261-276. qua lity of Mucheke and Shaga she Rivers as shown by the physical and chemical variables of the two rivers. Changes in the a ssemblages of diatom species a re also evident of changes in wa ter qua lity a long the rivers, thus a relationship between diatoms and water quality. Diatoms have an important role in biological monitoring of lotic systems as they has shown capacity to respond to changes in water quality. Biologic a I monitoring of wa ter qua lity using diatoms is a reliable method for water quality assessment and should therefore be adapted in research and by relevant govemment organizations.

BEYENE, T., LETTENMAIER, D.P. and KABAT, P., 2010. Hydrologic impacts of climate change on the Nile River Basin: implications of the 2007 IPCC scenarios. Climatic change, no. 100, vol. 3-4, pp. 433-461.

BIGGS, B. and KILROY, C., 2000. Stream periphyton monitoring manual: Niwa.

BIGGS, B.J. and THOMSEN, H.A., 1995. Disturbance of stream periphyton by perturbations in shear stress: time to structural failure and differences in community resistance. Journal of Phycology, vol. 1 , no. 2, pp. 233-241.

DUBE, D. and SWATUK, L.A., 2002. Stakeholder participation in the new water management approach: a case study of the Save catchment, Zimbabwe. Physics and Chemistry of the Earth, Parts $A / B / C$, vol. 27, no. 11, pp. 867-874.

DUDGEON, D., ARTHINGTON, A.H., GESSNER, M.O., KAWABATA, Z.-I., KNOWLER, D.J., LÉVÊQUE, C., NAIMAN, R.J., PRIEUR-RICHARD, A.-H., SOTO, D. and STIASSNY, M.L., 2006. Freshwater biodiversity: importance, threats, status and conservation challenges. Biological reviews, vol. 81, no. 2, pp. 163-182.

GENSEMER, R.W., 1991. The effects of $\mathrm{pH}$ and aluminum on the growth of the acidophilic diatom Asterionella ralfsii var. americana. Limnology and Oceanography, vol. 36, no. 1, pp. 123-131. 
GÓMEZ, N. and LICURSI, M., 2001. The Pampean Diatom Index (IDP) for assessment of rivers and streams in Argentina. Aquatic Ecology, vol. 35, no. 2, pp. 173-181.

HAMMER, O., HARPER, D. and RYAN, P., 2001. PAST (Paleontological Statistics) version 3.14. Software package for education and data analysis. Paleontología Electrónica, vol. 4, no. 1, p. 9.

HARDING, W., ARCHIBALD, C. and TAYLOR, J., 2005. The relevance of diatoms for water quality assessment in South Africa: A position paper. Water SA, vol. 31, no. 1, pp. 41-46.

HARDING, W. and TAYLOR, J., 2011. The South African Diatom Index (SADI): A Preliminary Index for Indicating Water Quality in Rivers and Streams in Southern Africa. Report to the Water Research Commission, Water Research Commission.

HARPER, D.M., 1992. Eutrophication of freshwaters: Springer.

JOWETT, I.G. and BIGGS, B.J., 1997. Flood and velocity effects on periphyton and silt accumulation in two New Zealand rivers. New Zealand Journal of Marine and Freshwater Research, vol. 31, no. 3, pp. 287-300.

KARR, J.R., 1981. Assessment of Biotic Integrity Using Fish Communities. Fisheries, vol. 6, no. 6, pp. 21-27. http://dx.doi.org/ 10.1577/1548-8446(1981)006<0021:AOBIUF>2.0.CO,2

KELLY, M., ADAMS, C. and GRAVES, A., 2001. The Trophic Diatom Index: A User's Manual, Revised Edition, Environment Agency.

KIM, K.C. and WEAVER, R.D., 1994. Biodiversity and landscapes: a paradox of humanity: Cambridge University Press.

MANGADZE, T., BERE, T. and MWEDZI, T., 2015. Epilithic diatom flora in contrasting land-use settings in tropical streams, Manyame Catchment, Zimbabwe. Hydrobiologia, vol. 753, no. 1, pp. 163-173.

MANGADZE, T., BERE, T. and MWEDZI, T., 2016. Choice of biota in stream assessment and monitoring programs in tropical streams: A comparison of diatoms, macroinvertebrates and fish. Ecological Indicators, vol. 63, pp. 128-143.

MAPIRA, J., 2011. Sewage treatment, disposal and management problems, and the quest for a cleaner environment in Masvingo city (Zimbabwe). Journal of Sustainable Development in Africa, vol. 13, no. 4.

METZELTIN, D. and LANGE-BERTALOT, H., 1988. Tropische Diatomeen in Südamerika, I: Koeltz Scientific Books, vol. 1.
MWEDZI, T., BERE, T. and MANGADZE, T., 2016. Macroinvertebrate assemblages in agricultural, mining, and urban tropical streams: implications for conservation and management. Environmental Science and Pollution Research, vol. 1-12.

PAPPAS, J.L. and STOERMER, E.F., 1996. Quantitative method for determining a representative algalsample count 1. Journal of Phycology, vol. 32, no. 4, pp. 693696.

PHIRI, C., DAY, J., CHIMBARI, M. and DHLOMO, E., 2007. Epiphytic diatoms associated with a submerged macrophyte, Vallisneria aethiopica, in the shallow marginal areas of Sanyati Basin (Lake Kariba): a preliminary assessment of their use as biomonitoring tools. Aquatic Ecology, vol. 41, no. 2, pp. 169-181.

PIPP, E., 2002. A regional diatom-based trophic state indication system for running water sites in Upper Austria and its overregional applicability. Paper presented at the Verh. Int. Ver. Theor. Angew. Limnol./Proc. Int. Assoc. Theor. Appl. Limnol./Trav. Assoc. Int. Limnol. Theor. Appl.

POTAPOVA, M.G. and CHARLES, D.F., 2002. Benthic diatoms in USA rivers: distributions along spatial and environmental gradients. Journal of biogeography, vol. 29, no. 2, pp. 167-187.

RIMET, F. and BOUCHEZ, A., 2011. Use of diatom life-forms and ecological guilds to assess pesticide contamination in rivers: lotic mesocosm approaches. Ecological Indicators, vol. 11, no. 2, pp. 489-499.

ROUND, F., 1991. Diatoms in river water-monitoring studies. Journal of Applied Phycology, vol. 3, no. 2, pp. 129-145.

SAROS, J. and FRITZ, S.C., 2000. Nutrients as a link between ionic concentration/composition and diatom distributions in saline lakes. Journal of Paleolimnology, vol. 23, no. 4, pp. 449-453.

SIGG, L. and STUMM, W., 1981. The interaction of anions and weak acids with the hydrous goethite (a-FeOOH) surface. Colloids and surfaces, vol. 2, no. 2, 101-117.

SMOL, J.P. and STOERMER, E.F., 2010. The diatoms: applications for the environmental and earth sciences. Cambridge University Press.

TAYLOR, J., VAN VUUREN, M.J. and PIETERSE, A., 2007a. The application and testing of diatom-based indices in the Vaal and Wilge Rivers, South Africa. Water SA, vol. 33, no. 1. 
TAYLOR, J.C., PRYGIEL, J., VOSLOO, A., PIETER, A. and VAN RENSBURG, L., 2007b. Can diatom-based pollution indices be used for biomonitoring in South Africa? A case study of the Crocodile West and Marico water management area. Hydrobiologia, vol. 592, no. 1, pp. 455-464.

TER BRAAK, C. and SMILAUER, P., 2002. Canoco for Windows version 4.5. Biometris-Plant Research International, Wageningen.

TER BRAAK, C.J. and VERDONSCHOT, P.F., 1995. Canonical correspondence analysis and related multivariate methods in aquatic ecology. Aquatic Sciences, vol. 57, no. 3, pp. 255-289.
VAN DAM, H., MERTENS, A. and SINKELDAM, J. A, 1994. coded checklist and ecological indicator values of freshwater diatoms from the Netherlands. Aquatic Ecology, vol. 28, no. 1, pp. 117-133, 1994. WERNER, D., 1977. The biology of diatoms. Univ of California Press, vol. 13.

WOOD, R.J., MITROVIC, S.M., LIM, R.P. and KEFFORD, B.J., 2016. The influence of reduced light intensity on the response of benthic diatoms to herbicide exposure. Environmental Toxicology and Chemistry, vol. 35, no. 9, pp. 2252-2260. http://dx.doi.org/10.1002/ etc. 3379 